\title{
"Poíesis" e política: o modelo intelectual de Octavio Paz
}

\author{
Horácio Costa
}

Há uns poucos dias, a câmara municipal de Karl Marx Stadt, centro industrial da Saxônia, na então Alemanha do Leste, por maioria de votos decidiu devolver à cidade seu antigo nome: Chemnitz. $O$ fato é duplamente significativo: em primeiro lugar, afirma o peso da identidade local numa das regiões mais conturbadas da história moderna. Esta troca de nomes leva-nos a compreender, também, que a Nova Europa, que se está forjando sob nossos olhos, provavelmente será uma comunidade em que a idéia de estadonação, fruto de um processo que se afirma na antevéspera do Renascimento e chega aos nossos dias, tenderá a ser substituída pela de região e pela de comunidade plurinacional. Ao governo centralizado, cioso defensor de um espaço nacional para maior proveito das classes que nele são hegemônicas - sejam elas representadas por burguesias exclusivistas ou por burocracias amorais - vemos insurgir-se um governo comunal que, nas novas condições históricas, reage contra as constrições às que estava submetido, restabelecendo sua afinidade histórica e ideológica com o governo cidadão da polis da antigüidade. A nova Karl Marx Stadt, esgotada na flor de seus 45 anos de idade, cede lugar à velha Chemnitz, que mostra surpreendentes sinais de vitalidade, com seus oito séculos de existência.

Em segundo lugar, esta substituição de nomes assume uma outra dimensão, desta vez simbólica, se nos detivermos a observar que o antigo nome da atual Chemnitz carregava consigo uma conotação nitidamente “internacionalista". A febre de troca de topônimos que se deu após a Revolução de Outubro e, na Europa do Leste, no pós-guerra não obedece, ao menos aparentemente, à mesma ordem de fenômenos que levou Alexandre e Constantino a rebatizar Rhacotis e Bizâncio por Alexandria e Constantinopla - ou, diga-se de passagem, a que levou o Sultão Mehmed II a substituir o nome desta última cidade por Istanbul, em 1453. Cada um desses potentados, ainda quando suas conquistas alargavam as fronteiras de suas fés religiosas e de seus sistemas políticos, buscava sua maior glória pessoal, ou de sua dinastia, seus validos, sua guarda, seus janízaros. $\mathrm{O}$ uso do nome de Karl Marx numa cidade fabril, gesto que dificilmente contaria com a aprovação do filósofo que jamais aceitou o termo "marxismo" enquanto vivia, contudo, está intimamente ligado à ideologia que se propôs como emancipatória do proletariado, do homem comum, exatamente para acabar com os delírios de poderosos que soem trocar nomes de cidades, como se de montaria, a seu bel-prazer. Que os filhos e os netos dos proletários que, em princípio, teriam sido os beneficiários da implantação desse sistema internacionalista e emancipador, queiram agora voltar a chamar sua cidade conforme o topônimo que foi roubado a seus pais ou avós num típico ato de arbítrio do Poder, não nos pode deixar de cativar. Entre as quatro paredes que assistem à vida de uma família, Chemnitz nunca chegou a ser Karl Marx Stadt; além da dúbia realidade dos cartazes, dos discursos de ocasião e da cartografia dos mapas contemporâneos, Karl Marx Stadt nunca substituiu a Chemnitz no âmbito da realidade maior, menos auto-evidente porem mais poderosa, que rege o ritmo interior da coletividade e funda a psicologia da grei.
HORÁCIO COSTA é professor de Literatura Brasileira na Universidade Nacional do México e autor de Satori (Editora lluminuras).

Este trabalho fol apresentado num coloquio organizado pela Universidade Complutense de Madri, no monastério de EI Escorial, entre os dlas 2 e 6 de julho de 1990.

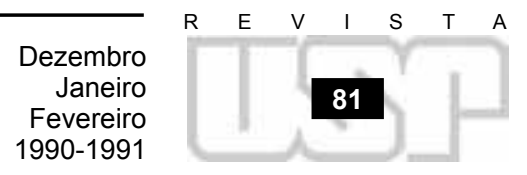


Há cerca de duzentos anos, na estação de posta de Chemnitz, um ancião proveniente da Boêmia fazia sua correspondência a caminho da Turíngia. Era Giacomo Casanova, que tentaria empregar-se como bibliotecário na corte ducal de Weimar. Lá chegando, descobriria que a posição já estava ocupada por um escritor residente: Goethe. A paisagem desta região da Alemanha, detestada pelo cortesão Casanova, é também a que favoreceu a formação do Sturm und Drang, movimento que, como poucos, estendeu sua influência sobre os destinos literários de meio mundo. Ainda, os operários têxteis de Chemnitz foram dos primeiros em organizar-se na Alemanha, solidarizando-se com as pessimas condições de vida a que estavam submetidos os trabalhadores das minas da vizinha Silésia. Chemnitz, como qualquer lugar da Europa do Leste e como toda a paisagem vivida em qualquer parte do mundo, está imantada de presenças, vozes e ecos de vozes de homens e de mulheres, que se sobrepõem, com suas idéias e seus ideais, suas paixões, seus medos e limitações, formando uma espessura profundamente humana.

O gesto de chamar Chemnitz de Karl Marx Stadt harmonizava-se com uma visão de mundo, finalista e utópica, que se instaurou na realidade de modo messiânico e se plantou no devir como a realização de uma utopia. No caso da Europa do Leste, o trânsito entre a projetada utopia e a distopia realizada se deu no curto período de duas ou três gerações. O que, em sua origem ideal, se apresentava como uma alternativa aos modelos civilizatórios até então conhecidos, revelou-se como uma forma, renovada e antiga, de barbárie. Em vez da polis, tivemos satrapias; em vez de Fídias, enormes cabeças de líderes, fundidas em bronze ou esculpidas em pedra, que hoje os cidadãos alegremente retiram dos espaços públicos. Em vez de discursos políticos reais, tivemos arengas; em vez da palavra que ilumina e analisa, tivemos a que obnubila, tergiversa e, servilmente, elogia. Em vez do poeta e do cidadão, tivemos funcionários e o líder máximo: a patética figura do "Conducator" e sua esposa "científica".

Regressemos, uma última vez, ao simbolismo da substituição do nome de Karl Marx Stadt por Chemnitz: o que pretende a comunidade que volta a chamar sua cidade com o nome ancestral é devolver à circulação social a espessura humana acima referida, a pluralidade de tempos e perfis e traços e vozes, que a nova ordem implantada no pós-guerra, com sua interpretação redutiva da história, tentara banir da vida coletiva. Esta reivindicação do passado se dá menos em função da restauração saudosista de uma tradição, que em nome de uma integração psíquica do corpus social consigo mesmo: é uma medida que a comunidade toma para tornar-se mais saudável, $€$ uma forma autoterapêutica; tanto quanto um ato político, $\hat{e}$ um ato poético. Implica na superação pragmática de uma distopia fundada na retórica pervertida do internacionalismo e no mito da revolução.

As transformações mundiais que presenciamos merecem um epíteto caro aos barrocos: são "prodigiosas". Em sua cadência, podemos minimizar o fato de que, como todos os processos sociais, elas se gestam numa somatória de espaços, individuais e públicos, no universo da vida cotidiana e no da cultura. Quando afloram e fazem história, é porque já estão prenhes de história. Sobretudo em seu período de gestação, a contribuição dos intelectuais $\varepsilon$, sob todos os ângulos, fundamental. Num mundo em que a globalização se acelera e se converte numa sua característica primordial, a consciência não conhece limites geográficos ou lingüísticos: está aqui e além, como o éter dos antigos; como a velocidade da luz, absorve as diferentes dimensões nas que nos inserimos e das quais nossos sentidos nos indicam apenas uma.

Duas são as condições necessárias e indissociáveis entre si para que a aventura da consciência se dê: a liberdade e a crítica. A primeira, sabemo-lo todos, não ê um direito dado e sim um direito adquirido por cada um dos indivíduos: a liberdade $e$, tanto quanto a crítica, uma atividade. A segunda, atributo central de toda modernidade, é a forma em que se traduz a liberdade na linguagem. Para que esta aventura da consciência individual se afirme em circunstâncias ótimas e possa enraizar-se na dimensão coletiva, um terceiro fator, não indissociável dos primeiros porém cuja presença os complementa, deve ser acrescentado: refiro-me aqui, como o fiz há pouco, à pulsão poética, que parte da percepção individual do que é real ou virtual e articula, como elemento de fundo, a linguagem crítica em liberdade.

Estamos reunidos para estudar a obra de Octavio Paz. Nela, como um todo, e de modo particular nos ensaios políticos que serão enfocados neste trabalho, estes três fatores 
se encontram em posição de notável equilíbrio. Nos ensaios que abordarei, percebemos um homem que exerce ativamente sua liberdade; neles identificamos um cidadão que, através do exercício crítico, encontra sua forma de radicação e de relativização da história; neles se transparenta um poeta que dialoga com o seu tempo e se expõe ao mundo que lhe foi dado viver. Já seja pelos valores sobre os quais se fundamenta, já seja pela sua capacidade de participação social, como forjadora de opinião no âmbito de um processo de mudanças vertiginosas, a obra de Octavio Paz assume um perfil definitivo: exemplo de liberdade e de crítica articuladas pela vivência poética, torna-se um elemento de liberação.

Liberador de consciências e, como tal, desconstrutor de mitos, Octavio Paz representa, outrossim, no contexto da cultura latino-americana atual, um exemplo de conciliação. Irei me referir primeiro à conciliação que se processa entre sua escritura poética e a ensaística; mais adiante voltaremos, sob um outro ângulo, à idéia de conciliação como elemento estruturador de sua obra.

Política e poresis, face bifronte da condição humana, salvo contadas exceções nas últimas gerações de escritores latino-americanos, estiveram dissociadas ou, ao contrário, indevidamente entrelaçadas. A ênfase dada em separado a cada um desses aspectos gerou, por um lado, estudos de ciência política que raras vezes superaram a marca da conjunturalidade e, por outro, posições poéticas intimistas que, ainda que capazes de problematizar o discurso subjetivo do

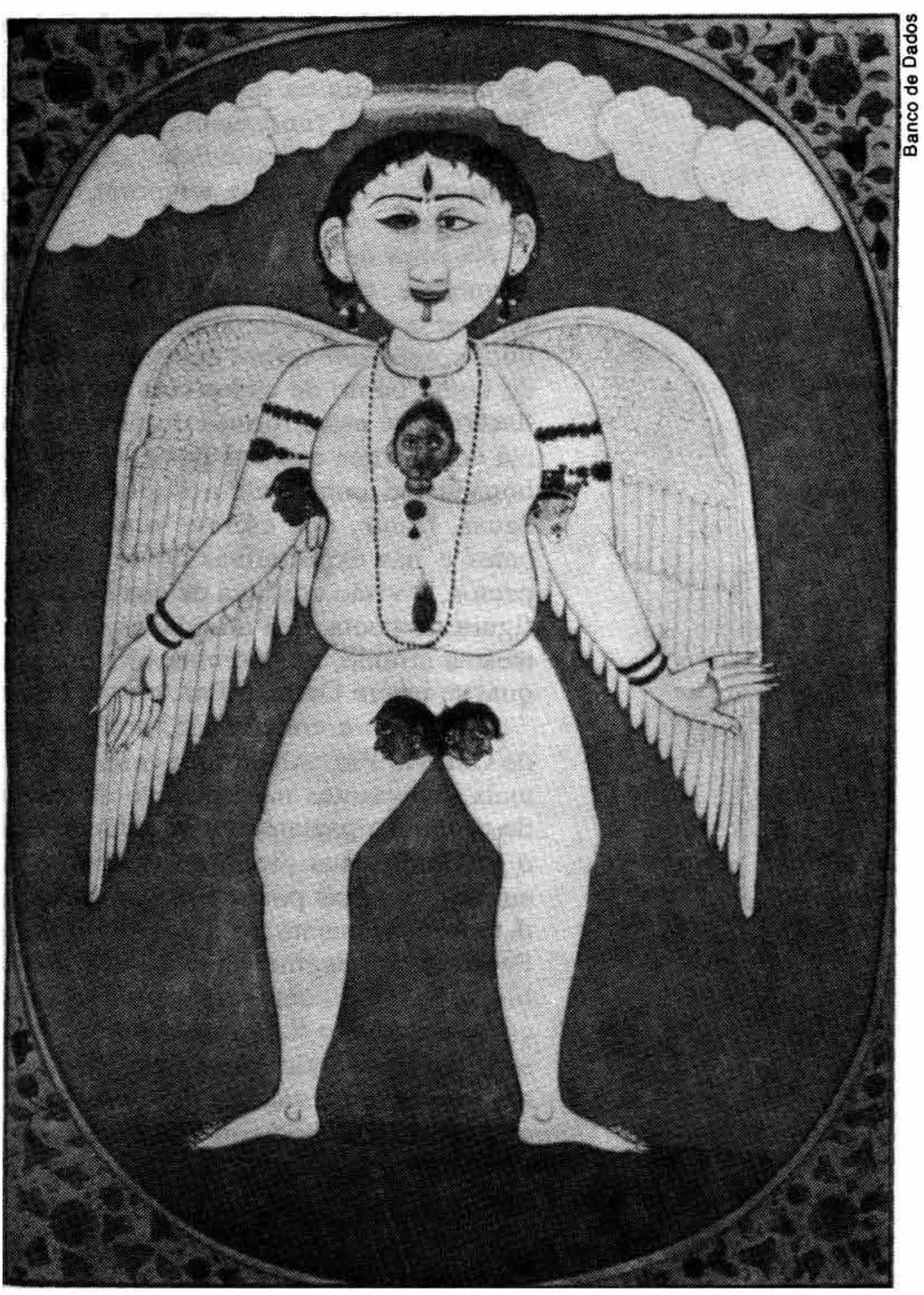
indivíduo na sociedade, acataram a triste divisão do trabalho intelectual entre o homem político e o homem sensível, que se opera na época contemporânea. Em oposição a isto, o entrelaçamento entre discurso político e poético levou à escritura de textos que denotam a ausência de um raciocínio claro em relação às questōes políticas ou sociais sobre as quais se debruçam, privilegiando antes o gênero da crônica política que o do ensaio. Ainda, implicou na afirmação de um tipo de poesia autodefinida como comprometida que, por sua vez, em nome da "conscientização social", abdicava da preocupação formal e do aspecto lúdico, inerentes a toda atividade artística.

Num caso ou no outro, a perdedora desta falsa oposição, ou desta não menos falsa confusão, foi a cultura latino-americana como um todo, e especialmente sua definição como produto de uma herança baseada na intercomunicação e no livre exercício dos discursos criativo e crítico, que refuta as limitaçōes epistemológicas impostas por uma concepção compartimentalizada da cultura e, conseqüentemente, afirma uma visão, ou uma tradição, antípoda a esta compartimentalização, a qual é próprio chamar-se humanística.

Nesse sentido, mais uma vez, a obra de Octavio Paz pode ser considerada como um ponto de equilíbrio entre as posiçōes acima mencionadas. Nas duas modalidades discursivas que aqui consideramos, tanto em sua escritura de poesia, como na de seus ensaios políticos, sentimos uma mútua e fértil contaminação entre ambas, sem que esta dupla operação leve a que a margem de diferença, ditada pelos gêneros escriturais específicos e pela posição do autor vis-à-vis à matéria tratada, entre cada uma delas, se borre. Em sua produção poética, observamos uma e outra vez a incidência de um substrato de

 
consciência histórica - Piedra de Sol, por exemplo, conforma um momento-chave, neste sentido, em sua poesia -, tanto quanto em Sor Juana Inés de la Cruz o las trampas de la fe, biografia na qual a reconstituição e a análise histórica da forma-mentis barroca joga um papel fundamental, percebemos a articulação poética que, como é óbvio, vai além da mera "literariedade" do texto, para construir uma forma de percepção e de devassamento da matéria temporal, que se espelha, como não é menos óbvio, no uso da linguagem.

Na obra de Paz o "extra-literário" - afastado por uns e idolatrado por outros - se harmoniza, sem fundir-se, à matéria literária e vice-versa. Assim sendo, em vez de privilegiar a construção de um texto “experimental" ou "hrbrido", ou de procurar a fusão num continuum verbal entre a escritura poética e o ensaio político, Octavio Paz, tomando como ponto de apoio uma concepção global de sua obra, trabalha no nível da coniciliação entre estas formas discursivas. A construção de sua obra ao redor deste paradigma ecoa, antes que nas posições bipolares acima referidas, no momento de fundação do humanismo ocidental: a dupla atividade, política e poética, de um poeta divisor de águas, Dante, que escreve o tratado De Monarchia imerso na mundividência, nos embates e nas expectativas do seu tempo, tratado este que complementa, sob muitos aspectos, a visão cósmica de sua Divina comédia. A pressuposição ética de integração, na figura do poeta, das atividades de crítica política e de escritura poética a partir de uma mesma atitude, nos permite identificar em Dante o arquétipo da "família espiritual" na qual se insere Octavio Paz, obra e homem.

Liberação e conciliação, política e poíesis: aqui está o núcleo do modelo intelectual de Octavio Paz. Abaixo me referirei, resumidamente, aos tópicos que me parecem ser os mais importantes na produção de sua ensaística pólítica. Limitar-me-ei a esta vertente da produção paziana por considerar que o espaço de um ensaio é insuficiente para fazer o jogo entre sua produção poética e sua ensaística política. Devido ao mesmo motivo, em vez de optar por seguir cronologicamente e por separado, obra por obra, a evolução de seu pensamento político, aludirei a ele segundo um padrão alternativo e sincrônico. Para tanto, imaginei uma leitura sintetizadora que se entrelaça com as circunstâncias biográficas do poeta, a partir de três momentos de sua vida que adquirem uma significação matricial ao longo de sua obra. Uma ressalva quanto ao procedimento que aqui desenvolverei: se ele parece-me funcional para a matéria tratada, o mesmo não diria se, em vez da ensaística de Paz, me detivesse sobre sua produção poética. Tenho presente que esta, ainda que fruto de uma vivência individual, é ao mesmo tempo transubjetiva e auto-referencial; como diz $\mathrm{Paz}$, "la poesía se escapa de historia y lenguaje aunque ambos sean su necesario alimento"(1).

Os momentos emblemáticos na vida e na obra de Paz que escolhi têm um valor em comum: representam, a meu ver, três "nascimentos" que levam, inter-relacionadamente, à consolidação de sua consciência histórico-política e temporal. São eles o seu nascimento propriamente dito, em 1914, sua participação no II Congresso Internacional de Escritores em Defesa da Cultura, em Valência, Espanha, em 1937, e sua estadia, como diplomata, na Índia, entre 1962 e 1968. É, portanto, apenas por obedecer a um princípio expositivo que considerarei, em seguida, estes três momentos em forma seqüencial. No esquema que seguirei, as datas mencionadas, embora cronologicamente sucessivas, se misturam, se substituem ou se anulam, em sua recorrência, sua alternância ou sua fuga: são, para usar uma expressão do próprio Paz, "signos em rotação". Ao redor delas percebemos uma combinatória na qual estas datas, consideradas individualmente ou numa vinculação binária ou triádica, e sempre numa relação interna de tensão irradiante, funcionam como núcleos aglutinadores da forma de consciência que aqui nos interessa. Com relação ao modelo intelectual antes apontado, ao qual fundamentam valores estáveis - o valor ético de liberação e o estético de conciliação - que não fazem mais que se perfilar e definir-se com nitidez crescente ao longo da obra de Paz, segundo um vetor de integração progressiva, a "rotação" destes "signos" representaria a outra face: é a porta para a vertigem e o caos, o convite à desintegração num universo instável. Aqui podemos compreender a natureza profunda da ensaística política e sócio-histórica de Paz: alêm de corresponder a um impulso de participação cidadã na história, comum a todos os poetas “integrais", ela é parte principal de seu esforço pessoal de fazer dialogar, em sua obra, a instância da integração, nomeada pelos valores éticos e estéticos que conformam o seu modelo, com a da desintegração, imposta pelo canto de sereia da realidade histórica objetiva. Mais uma vez, vemos presenciar-se o princípio da conciliação, numa segunda acepção, como me referi anteriormente. Em El laberinto de la sole-

1 El laberinto de la soledad, México. FCE, 1959, p. 135.

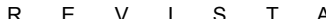
$\begin{array}{lllllll}R & E & V & \text { I } & \mathrm{S} & \mathrm{T} & \mathrm{A}\end{array}$ 
dad o poeta resume da seguinte maneira o que viemos dizendo:

"La historia tiene la realidad atroz de una pesadilla; la grandeza del hombre consiste en hacer obras hermosas y durables con la sustancia real de esa pesadilla. $O$ dicho de otro modo: transfigurar la pesadilla en vision, liberarnos, ast sea por un instante, de la realidad disforme por medio de la creacion''(2).

A data de 1914 corresponde ao nascimento de Octavio Paz para uma relação que dificilmente se estabiliza em quaisquer das equações políticas até agora experimentadas pela América Latina: Modernidade e Tradição. Naqueles anos o México atravessava um período especialmente turbulento de sua história. As posições ideológicas mais importantes que caracterizam a explosão que conhecemos como a Revolução Mexicana - que foi, como assinala Paz, tanto uma "revolução" burguesa, como uma "revolta" popular (3) - eram a "modernizadora", urbana, liberal-positivista, ou, para dizê-lo numa palavra, "histórica", e a "tradicionalista", que hoje chamaríamos "fundamentalista", ou ainda, "mítica", que expressava, de modo menos teórico que prático, a idéia de supressão da história não só como positividade mas também como progressão. Curiosamente, estas duas posições estavam presentes e em conflito no núcleo familiar de Paz, cujo avô apoiou por um período o regime do general Porfírio Díaz, e cujo pai representou os interesses do líder camponês Emiliano Zapata nos Estados Unidos ${ }^{(4)}$. Assim, o tema da relação entre modernidade e tradição, central em toda a obra ensaística de Paz, estava desenhado, de forma dialética, por um avô "histórico", formado sob as certezas "científicas" do século passado, e um pai "mítico", que descobre a verdadeira face da Revolução Mexicana no sentido da busca de uma origem longínqua e absoluta. A posição que Paz adotará diante desta oposição não poderia deixar de ser "crítica".

Portanto, a crítica da modernidade implica, igualmente, numa outra, complementária, da tradição, e vice-versa. Uma e outra vez em seus ensaios ou entrevistas Paz desmontará a retórica da "modernização" e julgará as fugidias noções de mundo "desenvolvido" e "subdesenvolvido". Antes de mais nada, Paz despe a "modernidade" de seu caráter de novidade e indica seu aspecto salvacionista ou providencialista:

"Las ideas que constituyen a la modernidad desde hace más de doscientos años y que integran lo que puede llamarse la tradición del futuro han perdido no sólo gran parte de su prestigio universal sino que incluso muchos dudan de su coherencia y de su valor. El progreso era una idea no menos misteriosa que la voluntad de Ala para los musulmanes o la Trinidad para los catolicos pero movio las almas y las voluntades durante dos siglos. Hoy nos preguntamos: ¿ progreso hacia adonde y para que?"(5).

O sentido desta operação é denunciar a modernização como um dos mitos centrais, e entretanto iniludíveis, do mundo contemporâneo, e afirmar o direito de cada um dos povos de encontrar a sua via para uma modernidade efetiva ("... como los otros patses de América Latina - diz $\mathrm{Paz}-$ México debe encontrar su propia modernidad. En cierto sentido debe inventarla") ${ }^{(6)}$. Ao mito ancilar da modernização, o do desenvolvimento, que em sua aplicação se revelou inefetivo ou mesmo prejudicial em mais de um contexto, propõe um substituto eficaz: a democratização ("El desarrollo por el desarrollo benefició únicamente al capitalismo extranjero y nacional. Además, hemos asistido al deterioro gradual pero inexorable de nuestra incipiente democracia. (...) Por eso la meta inmediata sigue siendo: democratización", dirá em El ogro filantrópico $)^{(7)}$. Como vemos, para Paz a modernização passa por uma solução menos técnica do que política: antes que vertical, é horizontal, antes que monologica, é dialógica e comunal.

Implicitamente, já estamos situados na crítica da tradição segundo Octavio Paz. Não me refiro aqui a este tópico a partir de um ponto de vista global, que considere a afloração conjunta de todas as tradições para formar um paideuma universal, pela primeira vez na história da humanidade. De modo particular, quero centrar-me sobre a análise do poeta sobre as origens da cultura política ibero-americana, que conformariam, com relação ao modelo "moderno", desenvolvido na Europa do Norte, uma outra tradição - que Paz repetidamente chama de "excêntrica" -, que organiza a inserção da América Ibérica na história ocidental.

A análise da tradição política ibero-americana, para ele, assume um aspecto duplo:

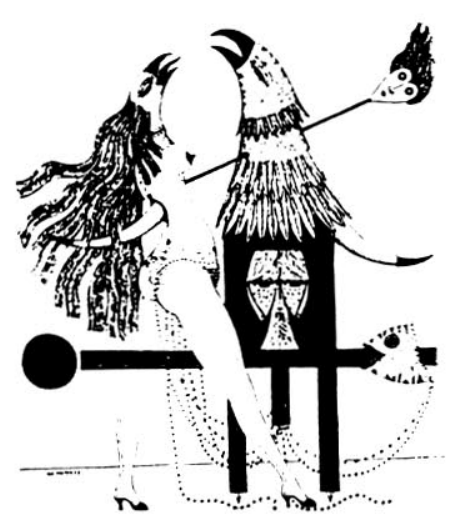

llustração para as lluminaçóes de Rimbaud, de Max Walter Svanberg
2 Idem, p. 94.

3 Ver "Vuelta a El laberinto de la soledad (Conversación con Octavio Paz)", Claude Fell, in Pasión critica, Móxl$c 0,1985, \mathrm{pp} .104-28$ (p. 114 segs.).
Também publlcado em El ogro filantropico, México, Joaquín Mortiz, 1979, pp. 17-37.

4 -MI abuelo materno fue un periodista y escritor conocido. Lucho contra la Intervención Francesa y fue partidario de Porfirio Dlaz, aunque al final de su vida se opuso al viejo dictador. Mi padre participo en la fevolucion Mo padro participo en la Revolución Mexicana y fue representante de Zapata en los Estados Unidos." "Octavio Paz", Rita Gullbert, In Pasión critica (op. cit., pp. 37-103), p. 64.

5 El ogro fllantrópico, México, Joaquín Mortiz, 1979, pp. 66-7.

6 Idem, p. 99.

7 Idem, p. 131. 
por um lado, enquanto definição das formas de governo e de administração e das tendências religiosas e culturais, é passível de uma crítica objetiva de traços explícitos. Neste processo, os aspectos que Paz define como fundamentais são a monarquia absoluta e o estado patrimonial, em conjunto com a ortodoxia religiosa e o neotomismo. Estas formas, todas pré-modernas, se correspondem para erigir uma tradição conservadora, fechada ao exterior e refratária à idéia de mudança. Referindo-se ao México, porém ecoando em sua análise um processo continental cujas diferenças regionais, mutatis mutandis, reiteram estes traços civilizacionais, em Sor Juana Inés de la Cruz o las trampas de la fe, Octavio Paz diz:

“(...) Nueva España era una sociedad más fuerte, próspera y civilizada que Nueva Inglaterra pero era una sociedad cerrada no solo al exterior sino al porvenir. (...) El dilema que se presento a los criollos mexicanos al otro día de la Independencia era tal vez insoluble: la continuidad condenaba a la nación a la inmovilidad y el cambio exigra la ruptura brutal, el desgarramiento. Continuidad y cambio no eran términos complementarios sino antagónicos e irreconciliables (...)"'(8).

Por outro lado, o poeta aponta o caráter difuso de uma "história oculta", de uma intra-história, perceptível menos numa ordem factual que numa outra simbólica, que em momentos se desvela e se afirma como uma tradição implícita, passível de uma leitura subjetiva. O México, com suas pirâmides, suas igrejas descomunais e seus monolitos aos próceres da independência e líderes da revolução, não só permite como sugere ao poeta uma interpretação desta tradição sub-reptícia à luz de uma racionalidade "outra" que a que costumeiramente preside à escritura historiográfica. Em "Posdata", ensaio que completa El laberinto de la soledad e é um esforço de compreensão arquetípica da matança de Tlatelolco, em 1968, Paz afirma: "la historia que vivimos es una escritura; en la escritura de la historia visible debemos leer las metamorfosis y los cambios de la historia invisible"(9).

Notemos, nesta passagem, que para o poeta esta história ou esta tradição paralela, justamente por estar viva, não se confunde com o imobilismo: antes que conformar uma "essência" imutável, que afirmaria um fatalismo histórico ou uma sobrevalorização da tradição sobre os destinos da sociedade, delineia uma tendência cuja característica maior é preservar um sentido de temporalidade próprio. Mesmo que esta tendência aponte para uma visão arquetípica - que, no caso da matança de Tlatelolco, seria a reincidência do rito sacrificial pré-hispânico -, esta visão, sujeita a "metamorfoses" e "câmbios", gera, ela também, um plano cujo movimento varia daquele que nos indica a consideração dos processos históricos à luz de sua materialidade, que sói ser o objeto da historiografia. Assim, a consideração do poeta de uma continuidade intra-histórica não se confunde com a assunção de um "destino manifesto"; em vez disso, abre caminhos para uma percepção totalizadora, na qual a razão crítica se exerce, ainda que despida de sua máscara logocêntrica.

$\mathrm{O}$ ponto de vista que organiza a análise da tradição política ibero-americana em $\mathrm{Paz}$, inclusive ao não se ater apenas a uma leitura de traços explícitos, afirma não só sua independência intelectual com relação ao discurso analítico "positivo", como traduz, por isso mesmo, um valor central em sua mesma leitura da tradição: é a confirmação de uma heterodoxia, se tomamos como referência o pensamento político acadêmico.

A reivindicação da heterodoxia em Paz tem um caráter funcional: afirmar a vertente "aberta" numa tradição "fechada". Ainda, apóia de forma direta o sentido de sua análise sobre o movimento explícito ou implícito da matéria histórica na formação da tradição política, análise que privilegia o valor transformacional desta última. Em poucas palavras, uma tradição que é passível de ser devassada em sua intimidade ou pode abrirse, ou, o que é mais provável, já se encontra, ao menos parcialmente, aberta. Ao contrário do que inúmeras vezes se considerou, seu estudo da tradição política mexicana - e, em certos aspectos, ibero-americana - está fundamentado antes por uma operação pragmática e liberadora que por um apelo ao irracional. O que busca Paz é transformar a tradição a que nos referimos em memória. Neste contexto, podemos compreender a posição do poeta frente a um processo histórico atual: a formação de uma comunidade norte-americana. Em seu recente livro de ensaios políticos, Pequeña crónica de grandes dias, raciocina: 
“'La anormal persistencia de ciertas lesiones historicas (...) no es signo de vigor sino de incertidumbre e inseguridad. Es una dolencia psiquica no menos perniciosa que la pérdida de la memoria historica. Asimilar el pasado, inclusive las derrotas, no es olvidarlo: es trascenderlo",(10).

Se, no pensamento político de Paz, à "modernização" corresponde a "democratização", à "tradição" corresponde sua "relativização".

Passemos ao tópico seguinte: o "nascimento" de Paz para um dos maiores conflitos do nosso tempo: Estado e Sociedade, temas que se vinculam aos anteriores e se relacionam, de modo evidente, com o motto deste ensaio.

A idéia que justificou o II Congresso Internacional de Escritores em Defesa da Cultura, em Valência, foi a de possibilitar à comunidade intelectual "progressista" da época solidarizar-se com um povo que resistia à violência do fascismo. Aos 23 anos, convidado por Pablo Neruda, o jovem Paz assiste ao evento como um dos representantes mexicanos $^{(11)}$. Na Espanha em guerra civil, Paz se expõe a uma dupla conjuntura: por um lado, testemunhando o abandono da facção republicana pelas potências capitalistas, começa a compreender a fragilidade do Estado liberal burguês frente aos regimes agressivos de direita e esquerda; isto o leva a perceber a afinidade profunda entre fascismo e totalitarismo, a partir da identificação do traço autoritário que vincula as ideologias aparentemente opostas. Por outro lado, presencia a mais um capítulo da difícil coexistência entre vida intelectual e política na época contemporânea. O II Congresso teve como predecessor o de Paris, no qual a cisão entre os defensores da livre expressão artística e os partidários do internacionalismo soviético se definira com a famosa polêmica entre Breton e Aragon. A partir de sua adesão ao primeiro grupo, Paz reconhece na livre expressão artística e na valorização do espírito crítico os antídotos para as receitas de participação dos intelectuais no processo político, preconizadas pelo dirigismo jdanovista, com sua concepção organicista da intelligentsia como parte da "vanguarda do proletariado", bem como sua proposta estética do realismo social-realista. Sob a superfície humanitária, o que este dirigismo pretendia era estabelecer a adesão da intelectualidade internacional à via revolucionária. Escrevendo sobre o II Congresso cinqüenta anos depois e apontando que sua grandeza moral residia na fraternidade e na generosidade, Paz se pergunta sobre sua debilidade, associando-a com a "perversión del esptritu revolucionario"(12). Imbuído de ideologia revolucionária até aquele momento, é a partir do Congresso de Valência e do pacto Hitler-Stalin, de 1938, que Paz começará a refutar a idéia de revolução política dirigida.

Agora nos interessa verificar sua análise do estado contemporâneo. Referir-me-ei primeiro aos dois sistemas que regeram bipolarmente os destinos da humanidade no período da guerra fria.

Em sua análise dos Estados Unidos e da União Soviética, Paz assinala um traço comum e uma contradição particular e central em cada qual. $\mathrm{O}$ traço comum: seu caráter de "novidade histórica". Suas contradições respectivas: a dupla face, no primeiro sistema, que lhe dá sua realidade ao mesmo tempo republicana e imperial; a oposição, no segundo, entre uma casta que se confunde com o partido e a burocracia, e uma sociedade industrial, numa equação cindida entre a ideologia que fundamenta o sistema e a realidade na qual ela se traduz. Ainda, sublinha, em ambos, sua "dependência do futuro", que se origina em ideologias salvacionistas: a puritana, filha da Reforma, e a marxista-leninișta, herdeira do pan-eslavismo czarista.

Como nos esclarece Octavio $\mathrm{Paz}$ em “"El espejo indiscreto", os Estados Unidos são "una democracia plutocrática" e uma "república imperial". Sobre o primeiro destes paradoxos, aponta que "la plutocracia provoca y acentúa la desigualdad; a su vez, la desigualdad convierte en quimeras las libertades politicas y los derechos individuales (...)" (13). Sobre o segundo, diz desdobrar-se "entre lo que son interiormente los Estados Unidos: una democracia, y lo que son en su acción hacia el exterior: un imperio. Libertad y opresión son las caras opuestas y complementarias de su ser nacional" (14).

Em "La democracia imperial”, Paz se questiona sobre a ausência de uma meta-história nos Estados Unidos, que poderia explicar sua dificuldade constitutiva de inserção na comunidade internacional:

(Nos Estados Unidos) "El bien común no consiste en una finalidad colectiva $o$ metahistórica sino en la coexistencia armoniosa de fines individuales.
10 Ver "Panamá y otros palenques", In Pequeña crónica de grandes dias, México, Fondo de cultura económica, 1990, p. 51.

11 Juntamente com os escritores Carlos Pellicer e José Mancisidor. Tanto a Pellicer e José Mancisidor. Tanto a obra poetica de Octavio Paz, ree Ralz del hombre, como seu idealismo politico juvenil, demonstrado por sua Ida ao lucatâ em 1937 para fundar uma escola para fllhos de operárlos e camponeses - polesis e politice - garantiam a Paz os requlsitos para sua presença no congresso.

12 In Pequefia crónica de grandes dlas, op. cit., p. 102.

13 Ver "El espejo Indiscreto", in El ogro fllantropico, op. clt., pp. 67-8. O trecho asim continua: "Cierto, la pluto cho assin continua: - Clorto, la pluto ra de abundancia y sf puede aligerar y aliviar las injustas diferencias entre los individuos y las clases. Pero lo ha hecho trasladando las desigualdades más escandalosas a los palses subdesarrollados".

14 Idem, p. 68.

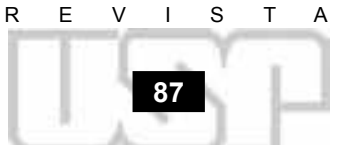


¿Pueden vivir las naciones sin creencias comunes y sin una ideologia metahistórica?"' (15)

Mais adiante, no mesmo ensaio, Paz assinala a contradição básica dos Estados Unidos, remetendo-se à sua fundação:

"El acto (y el acta) de fundación (...) se repite sin cesar en toda su historia:
cada uno de sus episodios se define no frente al pasado sino frente al futu-
ro. (...) Pero los Estados Unidos no están en el futuro, región inexistente:
están aquí y ahora, entre nosotros, los pueblos extraños de la historia. (...)
Ast, la contradicción de la sociedad norteamericana contemporánea: ser un
imperio y ser una democracia, es resultado de otra más honda: haber sido
fundada contra la historia y ser ella misma historia" (16).

Por sua vez, sobre a União Soviética, Octavio Paz dirá que sua novidade reside menos em sua estrutura econômica que em sua natureza política. Escrevendo há dez anos e inspirando-se em Besançon e em Castoriadis, como em sua análise dos Estados Unidos se inspirara em Tocqueville, Paz dirá que a União Soviética é tanto uma "ideocracia" um sistema que gravita em torno a uma ideologia, que se torna mais real que a realidade mesma - como uma "estratocracia" - um sistema no qual as atividades militares são as primordiais. Por um lado, "lo más real, los hombres, está al servicio de una abstracción ideológica"; por outro, "entre todas las desigualdades de esa sociedad quizá la más impresionante es la desproporción entre el nivel de vida de la población (...) y la enorme potencia militar del Estado". À parte a questão terminológica, para Paz o simulacro que se quis o "socialismo real" soviético nunca se confundiu com um socialismo sem adjetivos. Em vez disso, o resultado da revolução bolchevique é uma sociedade que reproduz a imagem do partido, cujos modelos históricos, destoantes da retórica que maneja, são "la Iglesia y el Ejército: sus miembros son clérigos y soldados; su ideal de comunidad, el convento y el cuartel", ao que agrega: "el cemento de la fusión entre el orden religioso y el orden militar es la ídeologia" (17). Na União Soviética, Paz assinala a transformação da ideologia em doutrina, cuja versão canônica é a do poder central. "Como en las teocracias de la Antigüedad, el sistema comunista realiza la fusión entre el poder y la idea" (18), diz. A elevação da ideologia política à doutrina universal implica, claro está, na afirmação de uma visão meta-histórica. Ideologia e doutrina se confundem para formar um único vetor: plasmar as estruturas plurais da história num projeto meta-histórico singular.

Em diferentes momentos de sua obra ensaística, Paz desenvolveu uma leitura sobre a natureza e a crise do sistema soviético. Sua análise da perversão do ideal socialista em ditaduras burocrático-militares foi por muitos anos exceção entre os intelectuais latinoamericanos, preparados pelo fermento da ortodoxia religiosa antes para absorver pacotes e ideologias que para confrontá-los com as realidades por eles criadas. Sua análise resulta correta, mesmo profética, à luz dos acontecimentos atuais. Não quero repetir seus pontos de vista, uma vez que já os utilizei quando me referi ao simbolismo da substituição do nome de Karl Marx Stadt por Chemnitz. Vale afirmar, entretanto, sua dúvida quando aponta que o "fim de um sistema" não necessariamente significa o "fim de um império" (19).

Se o desfazimento do Estado comunista, senão em sua realidade localizada, ao menos como modelo vigente em nível internacional, é hoje patente, ou, em outras palavras, se observamos a redução de sua meta-história à história na União Soviética, resta-nos saber como se dará o acomodamento à história dos Estados Unidos, despidos de uma meta-história. Velhos e novos agentes históricos - Europa e Oriente, o chamado "Terceiro Mundo" e minorias nacionais ou étnicas em todo o orbe - propõem aos dois sistemas até agora centrais a inserção definitiva de ambos na história, não considerando a existência ou a inexistência neles de uma meta-história.

Por outro lado, a transformação do estado soviético - "prodigiosa", mas também histórica - não significa, por si só, a mudança estrutural, benfazeja e necessária na relação Estado-sociedade no mundo em que vivemos. "La Unión Soviética puede estrechar sus lazos con el continente y convertirse en un inmenso mercado para los europeus. (...) Confieso, sin embargo, que me interesa más el sesgo que podrian dar a su politica los Estados Unidos" (20). Em “El ogro filantrópico" aponta Paz: 
"El Estado moderno (...) es una máquina que se reproduce sin cesar. En los países de Occidente, lejos de ser la dimensión polftica del sistema capitalista, una superestructura, es el modelo de las organizaciones económicas; las grandes empresas y negocios, a imitación suya, tienden a convertirse en Estados e imperios más poderosos que muchas naciones. En los últimos cincuenta años no hemos asistido a la esperada socialización del capitalismo sino a su paulatina pero irresistible burocratización. Las grandes compañtas transnacionales prefiguran ya un capitalismo burocrático", (21).

A este travestimento do Estado na época contemporânea, que a atual voga de diminuição do aparelho estatal pode antes reforçar que resolver, e à sua sede de imiscuir-se, sutilmente, sob a forma do capitalismo burocrático ou, mais avassaladoramente, sob a égide do burocratismo militar, a duras penas percebemos, em correspondência, uma transformação da sociedade. Se eventos como o da substituição de nome em Karl Marx Stadt nos indicam que a realidade internacional está mudando, nada nos garante que a recém-recobrada identidade da velha Chemnitz não perca seu sentido num mundo em que nomes de cidades e de indivíduos são intercambiáveis, senão supérfluos.

$\mathrm{Na}$ obra de Paz não encontramos soluções para esta conjuntura; talvez valesse recordar que ela é crítica e propedêutica antes que autoritária e conclusiva. Ainda assim, podem nos esclarecer a respeito algumas noções nela elaboradas a partir de sua estadia na Índia, que o poeta chama de "la otra versión del mundo indoeuropeo" (22). Refiro-me ao terceiro "nascimento" de Paz, que se sintetizaria nos dois pares que seguem, opositivos tanto em sua relação interna, quanto na razão simétrica inversa de seus termos tomados dois a dois: revolução-revolta e temporalidade linear-pluralidade temporal.

Dois são os eventos maiores que a estadia na Índia propicia a Paz, o primeiro deles relativo ao hemisfério de seu pensamento, o segundo ao de sua vida emocional: a percepção do Ocidente como uma totalidade - onde tem guarida a vertente "excêntrica" latino-americana -, e a descoberta do amor, que o leva à realização de sua vida sentimental ${ }^{(23)}$. O homem que, imerso na experiência da alteridade que possibilita a integração amorosa, e que vive em plenitude pela primeira vez, é o mesmo que não hesita em nomear, a partir de sua exposição à alteridade civilizacional que ocupa a Índia na sua visão de mundo, o traço dominante do Ocidente cristão. Em Corriente alterna, esta caracterização se coloca da seguinte maneira:

"El modelo de Occidente es la unidad indivisible, trátese de la metafisica (el ser), psicología (el yo) o del mundo social (la nación, la clase, los cuerpos políticos). Un modelo que, por lo demás, no corresponde a la realidad y que ésta destruye continuamente (...). La unidad es plural, contradictoria, en perpetuo cambio e insustancial"' (24).

Ato contínuo, compara esta situação com a da Índia:

"El pensamiento de Occidente arranca de la idea de sustancia, cosa, elemento, ser; el de la India de la relación, la interpenetración, la interacción, el flujo. Por eso define a lo Absoluto como cesación del cambio, esto es, como cesación de la relación y de la acción. La India no niega el Ser: lo ignora. Niega el cambio: es mays, ilusión. El pensamiento europeo no niega la relación: la ignora. Afirma el cambio: es el ser al desplegarse o manifestarse" (25).

Obviamente, a idéia de "revolução", neste contexto, aparece como algo supinamente ocidental. Ao contrário de seu sentido original - que "contiene la idea del tiempo ctclico y, en consecuencia, la de regularidad y repetición de los cambios" -, Paz analisa o valor semântico atual do termo: “cambio brusco y definitivo", para agregar:

"si ese cambio es definitivo, el tiempo cíclico se rompe y un nuevo tiempo comienza, rectilíneo. (...) La segunda acepción postula la primacía del futuro: el campo de gravitación de la palabra se desplaza del ayer conocido para el mañana por conocer" (26).

Tudo isto está contido numa expressão: concepção linear da história. Esta “contiene

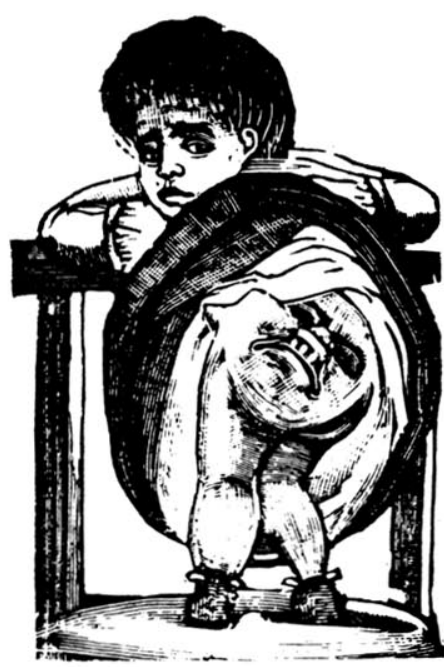

"O fenómeno", gravura de Posada
21 Ver "El ogro fllantrópico", in El ogro filantropico, op. cit., pp. 85-6.

22 In Conjunciones y disyunciones, Mexico, Joaquín Mortiz, 1969, p. 48.

23 Refiro-me ao casamento do poeta com Marle-Joseph Traminl, debalxo de uma árvore sagrada, nim. num "jardin de lecciones metaffsicas", em 1964.

24 In Corriente alterna, México, Sigio XXI, 17" ed., 1988, p. 132.

25 Idem, p. 139.

26 Idem, p. 151.

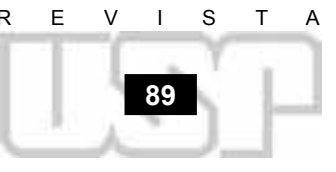


una triple exigencia", diz em Conjunciones y disyunciones. Parodiando a preceptiva dramática do neoclassicismo, de conhecida raiz aristotélica, explica:

"La primera es la unidad de tiempo: un presente lanzado siempre hacia el
futuro. La segunda es una trama única: la historia universal, se considere a
ésta como la manifestación del Absoluto en el tiempo, la expresión de la lu-
cha de clases o cualquiera otra hipótesis semejante. La tercera es la acción
continua de un personaje también único: la humanidad y sus máscaras su-
cesivas y transitorias" (27).

Contra esta concepção linear e limitante, a qual caraçterizam os valores de continuidade e de auto-reprodução, bem como a ilusão de regularidade, Octavio Paz identifica uma mudança no padrão temporal do Ocidente, que implica na superação da noção finalista de revolução e sua substituição por aquela mais dúctil e aberta de revolta. “(...) la historia moderna ha cambiado de orientación y (...) asistimos a una verdadera revuelta de los tiempos", postula em Corriente alterna ${ }^{(28)}$. Os tempos se rebelam frente ao jugo do futuro; o resultado desta crise é a revalorização da noção de "revolta social", vista como lugar por excelência de afirmação da pluralidade de agentes e de tempos sócio-históricos:

\section{"La pluralidad de protagonistas ha mostrado (...) que la trama de la histo- ria también es plural: no es una línea única sino muchas y no todas ellas rectas. Pluralidad de personajes y pluralidad de tiempos en marcha hacia muchos dondes (...)" (29).}

Esta revolta é "mundial, pero no es ecumênica" (30). Não cede, portanto, à miragem da universalidade, à redução a uma regra geral. Nela têm cabida todas as direções e todos os particularismos, ainda quando isso implique na ressurreição de tradições ou religiões, nacionalismos ou localismos. Com a crise do futuro e a desmontagem do mito da revolução, antes de cíclico, o desenho que nos apresenta o devir é multidimensional, senão fragmentário e contraditório; "plural" e, por isso mesmo, não-mítico e irredutível a uma configuração mitologizante. Como no caso da Chemnitz nos dias de hoje, futuro, passado e presente são uma única interrogação, cujo significado mínimo é indicar-nos que estamos diante de um "outro tempo".

“¿Cuál puede ser la contribución de la poesía en la reconstitución de un nuevo pensamiento político?", perguntou Paz em seu discurso de recepção do Prêmio Tocqueville, no ano passado. "No ideas nuevas sino algo más precioso y frágil: la memoria", indica. "Por la voz del poeta habla (...) la otra voz" (31). Para o "outro" tempo que começamos a experimentar, esta voz "outra", que em si relativiza as noções de tempo e indivíduo, de processo e de ser, voltará, provavelmente, a ocupar o seu antiqüíssimo papel de referência.

Ao referir-se acima aơ modelo intelectual de Octavio Paz - liberação e conciliação, política e polesis -, estabeleci dois valores para conciliação, reservando para o final deste ensaio apontar o segundo valor de liberação. Produto da sua crítica frente aos ideologemas políticos dominantes na época cuja superação presenciamos, em conjunção com uma percepção aguda do princípio poético que nela se concilia, a obra de Paz exemplifica uma via de liberação do imaginário. Mais do que isso, nela a conciliação entre os impulsos político e poético converte a liberação do imaginário em memória, uma memória não factual e sim poética. $O$ contato com esta obra fecunda transforma o leitor tanto no plano intelectual como naquele de sua vivência do imaginário.

Por isso neste texto podemos regressar à praça de Chemnitz, há cerca de duzentos anos, onde a um costado, na estação de posta, um ancião saudoso da velha ordem imutável espera prosseguir viagem. No espaço aberto, homens, mulheres e crianças estendem a lã e a seda sobre estacas e varais, enquanto comentam as novas vindas de França e reclamam dos salários. Sob as arcadas, outros cidadãos fazem contas com os comerciantes; perto do chafariz, de gansos saídos de um quadro de Chardin, grasna sua atemporalidade; o sol do meio-dia a tudo consome em seu vapor.

Nesta manhã, em Weimar, um poeta, receptivo às tempestades e aos impulsos de seu tempo, escreve. 